\title{
NEW CONVERSES OF THE JESSEN AND LAH-RIBARIČ INEQUALITIES II
}

\author{
ROZARIJA JAKŠIĆ AND JOSIP PEČARIĆ
}

Abstract. New converses of the Jessen and Lah-Ribarič inequalities for continuous convex functions are studied. Applications are given for generalized and arithmetic means, Hölder's inequality, Hadamard's inequality, and the inequalities of Giaccardi and Petrović.

Mathematics subject classification (2010): 26A51, 26E60, 97H30.

Keywords and phrases: Positive linear functionals, Jensen's inequality, Lah-Ribarič's inequality, convex functions, generalized means, arithmetic means, Hölder's inequality, Hadamard's inequality, inequalities of Giaccardi and Petrović.

\section{REFERENCES}

[1] P. R. BEESACK, J. E. PEČARIĆ, On the Jessen's inequality for convex functions., J. Math. Anal. Appl. 110 (1985), 536-552.

[2] P. S. Bullen, D. S. Mitrinović, P. M. Vasić, Means and their inequalities., (1987), D. Reidel Publishing Company (Dordrecht-Boston-Lancaster-Tokyo, 1988).

[3] S. S. Dragomir, Bounds for the normalized Jensen functional, Bull. Austral. Math. Soc. 74 (3) (2006), 471-478.

[4] S. S. DRAGOMIR, Some reverses of the Jensen inequality with application, RGMIA Res. Rep. Coll, 14 (2011), p. Art. 72., 2011.

[5] G. H. Hardy, J. E. Littlewood, G. Pólya, Inequalities, 1st ed. and 2nd ed., Cambridge University Press, Cambridge, England (1934, 1952).

[6] R. JAKŠIĆ, J. E. PEČARIĆ, New converses of the Jessen and Lah-Ribarić inequalities, Math. Inequal. Appl., accepted.

[7] B. Jessen, Bemaerkinger om konvekse Funktioner og Uligheder imellem Middelvaerdier I, Mat. Tidsskrift B (1931), 17-28.

[8] M. Klaričić BAKUla, J. E. PeČArić, J. Perić, On the converse Jensen inequality, Applied Mathematics and Computation 218 (2012).

[9] D. S. Mitrinović, I. B. Lacković, Hermite and convexity, Aequat. Math. 28, 229-232.

[10] D. S. Mitrinović, J. E. PeČArić, A. M. Fink, Classical and New Inequalities in Analysis, Mathematics and its Applications (East European Series), Kluwer Academic Publishers Group, 61, Dordrecht, 1993, ISBN 0-7923-2064-6, p. 740.

[11] J. E. PeČarić, F. Proschan, Y. L. Tong, Convex functions, Partial orderings and statistical applications, Academic Press Inc., San Diego 1992.

[12] J. E. PeČArić, P. R. BEesack, On Jessen's inequality for convex functions II, J. Math. Anal. Appl. 118 (1986), 125-144.

[13] M. Petrović, Sur une fonctionnelle, Publ. Math. Univ. Belgrade 1 (1932), 149-156.

[14] P. M. VASIĆ, J. E. PeČARIĆ, On the Jensen inequality for monotone functions I, Anal. Univ. Timişoara 1 (1979), 95-104. 